\title{
I 057 Pulmonary artery size and function after Fontan operation at young age: assessment with phase contrast magnetic resonance imaging
}

\author{
Danielle Robbers-Visser*1, Frank Helderman ${ }^{2}$, Jan L Strengers ${ }^{3}$, Lennie van \\ Osch-Gevers ${ }^{1}$, Livia Kapusta ${ }^{4}$, Peter MT Pattynama ${ }^{5}$, Ad JJC Bogers ${ }^{5}$, \\ Rob Krams ${ }^{2}$ and Willem A Helbing ${ }^{1}$
}

\begin{abstract}
Address: ${ }^{1}$ Erasmus MC - Sophia, Rotterdam, The Netherlands, ${ }^{2}$ Free University Medical Center, Amsterdam, The Netherlands, ${ }^{3}$ University Medical Center Utrecht, Utrecht, The Netherlands, ${ }^{4}$ UMC St Radboud, Nijmegen, The Netherlands and ${ }^{5}$ Erasmus MC, Rotterdam, The Netherlands

* Corresponding author
\end{abstract}

from I th Annual SCMR Scientific Sessions

Los Angeles, CA, USA. I-3 February 2008

Published: 22 October 2008

Journal of Cardiovascular Magnetic Resonance 2008, I0(Suppl I):AI82 doi:I0.II86/I532-429X-I0-SI-AI82

This abstract is available from: http://jcmr-online.com/content/I0/SI/AI82

(c) 2008 Robbers-Visser et al; licensee BioMed Central Ltd.

\section{Introduction}

little is known about the effects of long-term non-pulsatile flow on pulmonary artery (PA) growth after Fontan operation. Furthermore, the effects on flow variables and shear stress have not been studied in a patient group operated on at young age.

\section{Purpose}

In this study, we assessed PA size, flow variables, and shear stress long-term after Fontan operation at young age and compared them with healthy controls, using cardiovascular magnetic resonance (CMR) imaging.

\section{Methods}

14 patients ( 9 males, aged $13.1 \pm 4.0$ years, follow-up after Fontan completion 9.7 (5.4-16.8) years) and 17 healthy controls (9 males, aged $13.3 \pm 2.3$ years) were included. Flow measurements in the branch PA were made during a CMR study, using phase contrast velocity-encoded imaging. In patients, flow measurements were repeated during low-dose dobutamine stress of $7.5 \mu \mathrm{g} / \mathrm{kg} / \mathrm{min}$. Shear stress was determined according to a previously published method [1].

\section{Results}

CMR scanning and dobutamine administration was well tolerated by all subjects without side effects. Results of the flow studies and shear stress determination are summarized in Table 1 (NS = not significant).

\section{Conclusion}

PA diameter is normal in patients long-term after Fontan operation at young age. However, flow variables, distensibility and shear stress are significantly lower compared to healthy controls, implicating pulmonary endothelial and/ or vascular dysfunction.

\section{References}

I. J Am Coll Cardiol 2005, 45:846-854. 
Table I:

\begin{tabular}{|c|c|c|c|c|c|}
\hline & controls & patients, rest & patients, stress & $\mathrm{P}$-value (controls vs patients) & $\mathrm{P}$-value (rest vs stress) \\
\hline Heart rate (/min) & $72 \pm 12$ & $69 \pm 12$ & $93 \pm 17$ & NS & $<0.001$ \\
\hline Stroke index $\left(\mathrm{ml} / \mathrm{m}^{2}\right)$ & $3 \mid \pm 7$ & $19 \pm 7$ & $19 \pm 7$ & $<0.001$ & NS \\
\hline Total flow $\left(\mathrm{ml} / \mathrm{min} / \mathrm{m}^{2}\right)$ & $2189 \pm 463$ & $1244 \pm 74$ & $1705 \pm 308$ & $<0.001$ & $<0.001$ \\
\hline Average flow $(\mathrm{ml} / \mathrm{s})$ & $56 \pm 15$ & $28 \pm 6$ & $39 \pm 13$ & $<0.001$ & $<0.001$ \\
\hline Peak flow $(\mathrm{ml} / \mathrm{s})$ & $187 \pm 48$ & $55 \pm 31$ & $71 \pm 44$ & $<0.001$ & $<0.001$ \\
\hline Diameter (mm) & $16.2 \pm 1.7$ & $|5| \pm 2.7$. & $15.2 \pm 2.8$ & NS & NS \\
\hline Distensibility & $0.41 \pm 0.09$ & $0.22 \pm 0.06$ & $0.20 \pm 0.07$ & $<0.001$ & NS \\
\hline Shear stress $\left(\mathrm{N} / \mathrm{m}^{2}\right)$ & $0.84 \pm 0.14$ & $0.38 \pm 0.15$ & $0.50 \pm 0.18$ & $<0.001$ & $<0.001$ \\
\hline
\end{tabular}

Publish with Biomed Central and every scientist can read your work free of charge

"BioMed Central will be the most significant development for disseminating the results of biomedical research in our lifetime. " Sir Paul Nurse, Cancer Research UK

Your research papers will be:

- available free of charge to the entire biomedical community

- peer reviewed and published immediately upon acceptance

- cited in PubMed and archived on PubMed Central

- yours - you keep the copyright

Submit your manuscript here:

http://www.biomedcentral.com/info/publishing_adv.asp 